\title{
Reduced Fat Process Cheese Made from Young Reduced Fat Cheddar Cheese Manufactured with Exopolysaccharide-Producing Cultures ${ }^{1}$
}

\author{
A. N. Hassan, ${ }^{2}$ S. Awad, ${ }^{3}$ and V. V. Mistry \\ Midwest Dairy Foods Research Center, Dairy Science Department, South Dakota State University, Brookings 57007
}

\begin{abstract}
In a previous study, exopolysaccharide (EPS)-producing cultures improved textural and functional properties of reduced fat Cheddar cheese. Because base cheese has an impact on the characteristics of process cheese, we hypothesized that the use of EPS-producing cultures in making base reduced fat Cheddar cheese (BRFCC) would allow utilization of more young cheeses in making reduced fat process cheese. The objective of this study was to evaluate characteristics of reduced fat process cheese made from young BRFCC containing EPS as compared with those in cheese made from a 50/50 blend of young and aged EPS-negative cheeses. Reduced fat process cheeses were manufactured using young (2 d) or 1-mo-old EPS-positive or negative BRFCC. Moisture and fat of reduced fat process cheese were standardized to 49 and $21 \%$, respectively. Enzyme modified cheese was incorporated to provide flavor of aged cheese. Exopolysaccharide-positive reduced fat process cheese was softer, less chewy and gummy, and exhibited lower viscoelastic moduli than the EPS-negative cheeses. The hardness, chewiness, and viscoelastic moduli were lower in reduced fat process cheeses made from 1-mo-old BRFCC than in the corresponding cheeses made from 2-d-old BRFCC. This could be because of more extensive proteolysis and lower $\mathrm{pH}$ in the former cheeses. Sensory scores for texture of EPSpositive reduced fat process cheeses were higher than those of the EPS-negative cheeses. Panelists did not detect differences in flavor between cheeses made with enzyme modified cheese and aged cheese. No correlations were found between the physical and melting properties of base cheese and process cheese.
\end{abstract}

\footnotetext{
Received February 22, 2007.

Accepted April 18, 2007.

${ }^{1}$ Published with the approval of the director of the South Dakota Agricultural Experiment Station as Publication Number 3599 of the Journal Series. This research was supported by Midwest Dairy Foods Research Center and South Dakota Agricultural Experiment Station.

${ }^{2}$ Corresponding author: Ashraf.Hassan@sdstate.edu

${ }^{3}$ Current address: Department of Dairy Science and Technology, Alexandria University, Alexandria, Egypt.
}

Key words: reduced fat process cheese, exopolysaccharide, texture, functionality

\section{INTRODUCTION}

Process cheese is manufactured by blending different natural cheeses and additional ingredients including emulsifying salts. The type, characteristic, and age of the natural cheese, type and amount of emulsifying salt, and processing conditions play a major role in controlling the textural, viscoelastic, functional, microstructural, and sensorial properties of process cheese (Bowland and Foegeding, 2001; French et al., 2002; Glenn et al., 2003; Acharya and Mistry, 2005). The properties of process cheese also depend on its composition and the interaction between the protein network and the dispersed lipid phase (van Vliet, 1988; Bowland and Foegeding, 2001; Schar and Bosset, 2002).

The major component of most process cheese manufactured in the United States is Cheddar cheese. A typical process cheese contains about 15 to $20 \%$ aged cheese. Young cheese is preferred for textural and performance issues, whereas aged cheese offers better flavor. As cheese ages, fats and proteins break down through lipolysis and proteolysis into smaller units (Hickey et al., 2007). The aging process increases flavor intensity in cheese and decreases its emulsifying ability (Klostermeyer and Uhlman, 1998). Process cheese has many unique functional characteristics compared with natural cheese. These include meltability, plasticity, and shelf-stability (Drake et al., 1999a). The limitations of using natural cheese in making process cheese include low flavor stability due to ongoing biochemical and microbiological changes during storage, insufficient flavor intensity, and high cost due to the relatively long ripening time for most cheese varieties. This led to the development of enzyme-modified cheeses (EMC), which provide flavor many times stronger than the corresponding natural cheese. Enzyme-modified cheese offers other advantages such as low production costs, consistency, diverse flavor range, extended shelf life, low storage costs, and increased functionality. The blend of young cheese and the appropriate EMC produces a high-qual- 
ity yet economical process cheese (Moskowitz and Noelck, 1987; Kilcawley et al., 1998, 2000).

In addition to lack of flavor, young cheeses suffer from textural problems such as excessive firmness, rubbery texture, and decreased melting properties. The properties of Cheddar cheese used in process cheese making have a direct impact on the characteristics of the final product. Hydrocolloids have been used to improve the physical properties of process cheese (Drake et al., 1999a). Previous research indicated that exopolysaccharide (EPS)-producing lactic cultures improved characteristics of reduced fat Cheddar cheese (Awad et al., 2005a,b; Hassan et al., 2005). Young (2 d to 1 mo old) reduced fat Cheddar cheese made with EPS-producing cultures was softer, smoother, and less curdy, gummy, and rubbery than that made with non-EPS-producing cultures. These modifications in the textural and functional properties of young cheeses made with EPS-producing cultures in combination with EMC might improve texture and flavor of reduced fat process cheese made from young, base reduced fat Cheddar cheese (BRFCC). The objective of this study was to evaluate characteristics of reduced fat process cheese made from young BRFCC containing EPS as compared with those in cheese made from a 50/50 blend of young and aged EPS-negative cheeses.

\section{MATERIALS AND METHODS}

\section{Cheddar Cheese Making}

Raw milk was obtained from the Dairy Research and Training Facility at South Dakota State University. Three replicates of Cheddar cheese were manufactured from 3 different batches of standardized ( $2 \%$ fat) pasteurized milk (heated to $63^{\circ} \mathrm{C}$ for $30 \mathrm{~min}$ and cooled to $31^{\circ} \mathrm{C}$ ) according to Awad et al. (2005a). Cheese milk $(200 \mathrm{~kg}$ ) was assigned to 2 double-O cheese vats (Kusel Equipment Co., Watertown, WI). The following 3 treatments of cheese were used: 1) RFC: reduced fat control cheese made with a non-EPS-producing commercial Cheddar starter culture (DVS 850, Chr. Hansen Lab, Milwaukee, WI; $0.02 \% \mathrm{wt} / \mathrm{wt}$ ), 2) EPSA: reduced fat cheese made with the ropy strain Lactococcus lactis ssp. cremoris JFR1 (The University of Georgia, 2\% vol/wt), 3) EPSB: reduced fat cheese made with a capsule-forming nonropy Streptococcus thermophilus 3855S (Hassan et al., 1995; 0.7\% vol/wt) plus a non-EPS-producing commercial Cheddar starter culture (DVS 850, Chr. Hansen Lab; $0.013 \%$ wt/wt). In addition, cheese ripening cultures (DVS LH32, $2.75 \mathrm{~g} / 100 \mathrm{~kg}$ of milk and CR213, $2.75 \mathrm{~g} / 100 \mathrm{~kg}$ of milk) from Chr. Hansen Lab were also used in all treatments. Cultures were added to milk $\left(31^{\circ} \mathrm{C}\right)$, which was ripened for $1 \mathrm{~h}$. Chymosin (Chymax, Chr. Hansen Lab) was added to milk at the rate of $0.01 \%$ (vol $/ \mathrm{wt}$ ). The coagulum was cut within 30 min and cooked to $39^{\circ} \mathrm{C}$ over $30 \mathrm{~min}$ and held at this temperature for 30 more min after a healing period of 20 min. After whey drainage, the curd was cheddared and then milled when the $\mathrm{pH}$ reached 5.4. Curd was salted at $2.2 \%$ in 3 equal applications over $15 \mathrm{~min}$, hooped in rectangular blocks, and pressed overnight at $2.5 \mathrm{~kg} / \mathrm{cm}^{2}$. Cheese was kept in the ripening room at $4^{\circ} \mathrm{C}$ for up to $1 \mathrm{mo}$.

\section{Reduced Fat Process Cheese Making}

The following 7 pasteurized reduced fat process cheese treatments were used in this study: 1) RFCyoung $=$ process cheese made from 2 -d-old reduced fat Cheddar cheese containing no EPS, 2) EPSA-young = process cheese made from 2 -d-old reduced fat Cheddar cheese containing EPS produced by L. lactis ssp. cremoris JFR1, 3) EPSB-young = process cheese made from 2-d-old reduced fat Cheddar cheese containing capsular EPS produced by Strep. thermophilus 3855S, 4) RFCblend $=$ process cheese made from a 50/50 blend of young ( $2 \mathrm{~d}$ old) and aged (6 mo old) reduced fat Cheddar cheese containing no EPS, 5) RFC-1 mo = process cheese made from 1-mo-old reduced fat Cheddar cheese containing no EPS, 6) EPSA-1 mo = process cheese made from 1-mo-old reduced fat Cheddar cheese containing EPS produced by L. lactis ssp. cremoris JFR1, 7) EPSB-1 mo $=$ process cheese made from 1 -mo-old reduced fat Cheddar cheese containing capsular EPS produced by Strep. thermophilus 3855S. Moisture and fat were standardized to 49 and $21 \%$, respectively. The emulsifier (disodium phosphate duohydrate, Innophos Inc., Cranbury, NJ) was added at 3\%. A Damrow single auger, direct steam injection cheese cooker (model No. 84-062, Damrow, Fond du Lac, WI) was used for reduced fat process cheese manufacture. Steam injection at $4.2 \mathrm{~kg} /$ $\mathrm{cm}^{2}$ was used, and ingredients were pasteurized at $74^{\circ} \mathrm{C}$ for $2 \mathrm{~min}$. Reduced fat process cheese was packaged and stored at $4^{\circ} \mathrm{C}$ for $2 \mathrm{~d}$ before analyses. The EMC (Chr. Hansen) was used at a level of $0.6 \%$ in all reduced fat process cheeses made using 2-d-old or 1-mo-old BRFCC.

\section{Chemical Composition of Cheese}

Cheddar and process cheeses were analyzed for moisture by the oven method (AOAC, 2000; method 926.08), salt by chloride analyzer (model 926, Nelson Jameson Inc., Marshfield, WI), fat by Mojonnier (AOAC, 2000; method 933.05), and total protein by macro-Kjeldahl (AOAC, 2000; method 920.123). The $\mathrm{pH}$ was measured in slurry prepared by macerating $20 \mathrm{~g}$ of grated cheese in $20 \mathrm{~mL}$ of deionized water. The free oil in process 
cheese was measured by the method described by Kindstedt and Rippe (1990).

\section{Texture Profile Analysis}

Cheeses were cut into cylindrical samples of $30 \mathrm{~mm}$ high $\times 28.5 \mathrm{~mm}$ diameter using a cork borer and a wire cutter, placed in plastic bags, sealed (to prevent dehydration), and kept at $20^{\circ} \mathrm{C}$ for $1 \mathrm{~h}$. A 2-bite compression test was performed using the Instron Universal Testing Machine (model SINTECH 2/D MTS Systems Corp., Eden Prairie, MN) with a 45.4-kg load cell. A $25 \%$ compression test was used, and the crosshead speed was $50 \mathrm{~mm} / \mathrm{min}$. Hardness, cohesiveness, gumminess, chewiness, and adhesiveness were determined in triplicate from the texture profile curve as described by Bourne (1978).

\section{Viscoelastic Measurements}

Cheeses were sliced into thin disks $(\sim 3 \mathrm{~mm}$ thick and $28.5 \mathrm{~mm}$ in diameter) with a cheese slicer, placed into plastic bags to prevent dehydration, and stored at $20^{\circ} \mathrm{C}$ for $1 \mathrm{~h}$ before analysis. Dynamic oscillatory experiments were performed at $20 \pm 1^{\circ} \mathrm{C}$ using a Viscoanalyzer (ATS Rheosystems, Rheologica Instrument Inc., Bordentown, $\mathrm{NJ}$ ) equipped with an MP parallel plate geometry (plate diameter $=30 \mathrm{~mm}$ ) as described by Hassan et al. (2005). The stress sweep test used logarithmic increments from 1 to $2,000 \mathrm{~Pa}$ at a frequency of oscillation of $1.5 \mathrm{~Hz}$. The elastic $\left(\mathrm{G}^{\prime}\right)$, viscous $\left(\mathrm{G}^{\prime \prime}\right)$, and complex $\left(G^{*}\right)$ moduli were recorded as a function of stress.

Stress relaxation was applied at $700 \mathrm{~Pa}$ with a strain rise of $150 \mathrm{~s}$, and a relaxation time of $150 \mathrm{~s}$. The following parameters were evaluated according to Brown et al. (2003): Instantaneous compliance $\left(J_{0}\right)$, which is the compliance at time zero; maximum compliance $\left(J_{\max }\right)$, which is the peak compliance at $150 \mathrm{~s}$; and $J_{\text {rec }}$, which is the compliance after recovery.

Frequency sweep was carried out at $20 \pm 1^{\circ} \mathrm{C}$ and a constant stress of $750 \mathrm{~Pa}$ with increasing frequency from 0.1 to $200 \mathrm{~Hz}$. Viscoelastic moduli were recorded as a function of frequency, and the slope of the loglog plots was calculated to determine the extent of the moduli's frequency-dependence.

\section{Estimating Softening Point and Flow Characteristics}

The cheese block was cut into slices $(\sim 7 \mathrm{~mm}$ thickness) perpendicular to the long axis of the block using an electric food slicer. Cylindrical pieces $(\sim 30 \mathrm{~mm}$ in diameter and $5 \mathrm{~g}$ ) were cut out with a cork borer. The modified squeeze-flow method developed by Muthukumarappan et al. (1999) was used to determine the soft-
Table 1. Chemical composition of reduced fat Cheddar cheese used in making reduced fat process cheese ${ }^{1}$

\begin{tabular}{|c|c|c|c|c|c|}
\hline Treatment & Moisture & Fat & Protein & Salt & $\mathrm{pH}$ \\
\hline & & {$[9$} & & {[} & \\
\hline RFC & $43.16^{\mathrm{b}}$ & $21.74^{\mathrm{a}}$ & $31.28^{\mathrm{a}}$ & $1.40^{\mathrm{a}}$ & $5.18^{\mathrm{a}}$ \\
\hline EPSA & $47.08^{\mathrm{a}}$ & $19.80^{\mathrm{b}}$ & $29.11^{b}$ & $1.32^{\mathrm{a}}$ & $5.13^{\mathrm{a}}$ \\
\hline EPSB & $43.75^{\mathrm{b}}$ & $21.65^{\mathrm{a}}$ & $30.84^{\mathrm{a}}$ & $1.36^{\mathrm{a}}$ & $5.21^{\mathrm{a}}$ \\
\hline
\end{tabular}

${ }^{\text {a.b }}$ Means within the same column with no common superscript differ $(P<0.05)$.

${ }^{1} \mathrm{RFC}=$ reduced fat Cheddar cheese made using an exopolysaccharide (EPS) nonproducing culture; EPSA = reduced fat Cheddar cheese made using an EPS-producing culture (Lactococcus lactis ssp. cremoris JFR1); EPSB = reduced fat Cheddar cheese made using a capsular EPS-producing culture (Streptococcus thermophilus 3855S).

ening point and flow characteristics of cheese at a constant oven temperature of $70^{\circ} \mathrm{C}$.

\section{Sensory Evaluation}

Six experienced panelists graded coded samples of cheese. Samples were cut into cubes $(15 \times 15 \times 15 \mathrm{~mm})$ and presented at room temperature in identical plastic sample cups labeled with random 3 digital numbers and sealed with plastic lids to minimize moisture loss. Hand firmness, hand springiness, first bite firmness, first bit fracturability, chewdown degree of breakdown, chewdown cohesiveness, chewdown adhesiveness, chewdown smoothness, and residual smoothness of mouth coating were evaluated on a 1 - to 9 -point scale with $1=$ low, $5=$ medium, and $9=$ high as described by Brown et al. (2003). Overall cheese flavor scores of $1=$ poor, $5=$ average, and $9=$ excellent were also used.

\section{Statistical Analysis}

Data reported are the average of 3 measurements per replicate. Reduced fat process cheeses were made 3 times for a total of 21 cheeses. The GLM procedure using SAS statistical analysis software package (SAS, 1999) was used for ANOVA. Differences were considered significant at $P<0.05$.

\section{RESULTS AND DISCUSSION}

\section{Cheddar Cheese Composition}

The chemical composition of 2-d-old BRFCC is summarized in Table 1 . In agreement with previous findings (Awad et al., 2005a), the EPS-producing culture ( $L$. lactis ssp. cremoris JFR1) increased moisture of Cheddar cheese $(P<0.05)$. This resulted in a lower fat and protein percentage. No differences $(P>0.05)$ were observed in $\mathrm{pH}$ or salt among 2 -d-old cheeses. The protein level in BRFCC ranged from 29 to $31 \%$. 
Table 2. Formulations of reduced fat process cheeses ${ }^{1}$

\begin{tabular}{lccccccc}
\hline Ingredient (\%) & $\begin{array}{c}\text { RFC- } \\
\text { young }\end{array}$ & $\begin{array}{c}\text { EPSA- } \\
\text { young }\end{array}$ & $\begin{array}{c}\text { EPSB- } \\
\text { young }\end{array}$ & $\begin{array}{c}\text { RFC- } \\
\text { blend }\end{array}$ & $\begin{array}{c}\text { RFC- } \\
1 \text { mo }\end{array}$ & $\begin{array}{c}\text { EPSA- } \\
1 \text { mo }\end{array}$ & $\begin{array}{c}\text { EPSB- } \\
1 \text { mo }\end{array}$ \\
\hline 2-d-old reduced fat Cheddar & 74.75 & 81.25 & 76.40 & 37.91 & - & - & - \\
1-mo-old reduced fat Cheddar & - & - & - & - & 74.75 & 81.25 & 76.40 \\
6-mo-old reduced fat Cheddar & - & - & - & 37.91 & - & - & - \\
Enzyme-modified cheese & 0.58 & 0.58 & 0.58 & - & 0.58 & 0.58 & 0.58 \\
Anhydrous milk fat & 5.02 & 4.93 & 4.77 & 4.93 & 5.02 & 4.93 & 4.77 \\
Emulsifier & 3.00 & 3.00 & 3.00 & 3.00 & 3.00 & 3.00 & 3.00 \\
Salt & 0.82 & 0.74 & 0.82 & 0.74 & 0.82 & 0.74 & 0.82 \\
Calculated composition (\%) & & & & & & & \\
Fat & 21.0 & 21.0 & 21.0 & 21.0 & 21.0 & 21.0 & 21.0 \\
Moisture & 49.0 & 49.0 & 49.0 & 49.0 & 49.0 & 49.0 & 49.0 \\
Salt & 1.80 & 1.81 & 1.81 & 1.79 & 1.80 & 1.81 & 1.81 \\
\hline
\end{tabular}

${ }^{1} \mathrm{RFC}=$ process cheese made from 2 -d-old reduced fat Cheddar cheese containing no exopolysaccharide (EPS). EPSA = process cheese made from 2-d-old reduced fat Cheddar cheese containing EPS produced by Lactococcus lactis ssp. cremoris JFR1; EPSB = process cheese made from 2-d-old reduced fat Cheddar cheese containing capsular EPS produced by Streptococcus thermophilus $3855 \mathrm{~S}$; RFC-blend = a 50/50 blend of young $(2 \mathrm{~d}$ old $)$ and aged $(6$ mo old $)$ reduced fat Cheddar cheese containing no EPS.

${ }^{2}$ Disodium phosphate duohydrate.

\section{Reduced Fat Process Cheese Formulations and Actual Chemical Composition}

Reduced fat process cheese formulations are shown in Table 2. A higher amount of Cheddar cheese was used in making EPSA than in making RFC. However, because of the higher yield of the former base cheese (Awad et al., 2005a), a similar amount of milk would be used in the manufacture of both reduced fat process cheeses. There was no difference in the amount of anhydrous milk fat (AMF), emulsifier, and salt used in all cheeses. There were no differences $(P>0.05)$ in chemical composition and $\mathrm{pH}$ among all reduced fat process cheeses (Table 3).

\section{Textural Characteristics of Reduced Fat Process Cheese}

The hardness of reduced fat process cheeses is shown in Table 4. The RFC-blend was softer than all reduced fat process cheeses made from 2-d-old BRFCC. Although having the same composition, reduced fat process cheeses made using 2-d-old EPS-positive BRFCC were softer $(P<0.05)$ than the corresponding cheese made using the EPS-negative BRFCC. Awad et al. (2005b) found that young Cheddar cheese containing EPS was softer than that made with no EPS. This was due, in part, to the higher moisture level in the former cheese. However, because there were no differences in chemical composition and $\mathrm{pH}$ among all reduced fat process cheeses made from 2-d-old BRFCC, the differences in hardness should be related to characteristics of the BRFCC. The type, characteristic, and age of the base cheese play a major role in controlling the textural, viscoelastic, functional, microstructural, and sensorial properties of process cheese (Bowland and Foegeding, 2001; French et al., 2002; Glenn et al., 2003; Acharya and Mistry, 2005). Major differences in texture and microstructure were seen between EPS-positive and

Table 3. Chemical composition (\%) and $\mathrm{pH}$ of reduced fat process cheeses ${ }^{1}$

\begin{tabular}{|c|c|c|c|c|c|}
\hline Treatment & Fat & Protein & Moisture & Salt & $\mathrm{pH}$ \\
\hline & \multicolumn{4}{|c|}{$\%$} & \\
\hline RFC-young & $21.1 \pm 0.36$ & $22.3 \pm 0.28$ & $48.8 \pm 0.13$ & $1.89 \pm 0.03$ & $5.64 \pm 0.02$ \\
\hline EPSA-young & $21.1 \pm 0.32$ & $22.2 \pm 0.18$ & $48.7 \pm 0.16$ & $1.87 \pm 0.03$ & $5.68 \pm 0.03$ \\
\hline EPSB-young & $21.0 \pm 0.21$ & $22.3 \pm 0.24$ & $48.8 \pm 0.13$ & $1.83 \pm 0.03$ & $5.68 \pm 0.02$ \\
\hline RFC-blend & $21.1 \pm 0.23$ & $23.0 \pm 0.50$ & $48.7 \pm 0.32$ & $1.82 \pm 0.05$ & $5.72 \pm 0.03$ \\
\hline RFC-1 mo & $20.8 \pm 0.43$ & $22.1 \pm 0.43$ & $48.9 \pm 0.54$ & $1.86 \pm 0.06$ & $5.72 \pm 0.05$ \\
\hline EPSA-1 mo & $21.1 \pm 0.34$ & $22.0 \pm 0.56$ & $49.1 \pm 0.34$ & $1.81 \pm 0.07$ & $5.66 \pm 0.06$ \\
\hline EPSB-1 mo & $20.9 \pm 0.54$ & $22.4 \pm 0.47$ & $48.9 \pm 0.45$ & $1.85 \pm 0.04$ & $5.69 \pm 0.04$ \\
\hline
\end{tabular}

${ }^{1} \mathrm{RFC}=$ process cheese made from 2 -d-old reduced fat Cheddar cheese containing no exopolysaccharide (EPS). EPSA = process cheese made from 2-d-old reduced fat Cheddar cheese containing EPS produced by Lactococcus lactis ssp. cremoris JFR1; EPSB = process cheese made from 2-d-old reduced fat Cheddar cheese containing capsular EPS produced by Streptococcus thermophilus 3855S; RFC-blend = a 50/50 blend of young $(2 \mathrm{~d}$ old $)$ and aged $(6 \mathrm{mo}$ old $)$ reduced fat Cheddar cheese containing no EPS. Young = made from 2 $\mathrm{d}$-old base cheese, $1 \mathrm{mo}=$ made from 1-mo-old base cheese . 
Table 4. Texture profile analysis of reduced fat process cheeses ${ }^{1}$

\begin{tabular}{lcccccc}
\hline Treatment & $\begin{array}{c}\text { Hardness } \\
(\mathrm{N})\end{array}$ & $\begin{array}{c}\text { Cohesiveness } \\
(\text { ratio })\end{array}$ & $\begin{array}{c}\text { Adhesiveness } \\
(\mathrm{J})\end{array}$ & $\begin{array}{c}\text { Springiness } \\
(\mathrm{mm})\end{array}$ & $\begin{array}{c}\text { Gumminess } \\
(\mathrm{N})\end{array}$ & $\begin{array}{c}\text { Chewiness } \\
(\mathrm{J})\end{array}$ \\
\hline RFC-young & $22.1^{\mathrm{a}}$ & $0.86^{\mathrm{ab}}$ & $0.13^{\mathrm{a}}$ & $4.4^{\mathrm{b}}$ & $19.1^{\mathrm{a}}$ & $83.9^{\mathrm{a}}$ \\
EPSA-young & $16.4^{\mathrm{c}}$ & $0.84^{\mathrm{ab}}$ & $0.13^{\mathrm{a}}$ & $4.3^{\mathrm{b}}$ & $13.8^{\mathrm{c}}$ & $59.5^{\mathrm{c}}$ \\
EPSB-young & $19.6^{\mathrm{b}}$ & $0.88^{\mathrm{a}}$ & $0.14^{\mathrm{a}}$ & $4.4^{\mathrm{b}}$ & $17.1^{\mathrm{b}}$ & $74.6^{\mathrm{b}}$ \\
RFC-blend & $12.6^{\mathrm{d}}$ & $0.63^{\mathrm{d}}$ & $0.17^{\mathrm{a}}$ & $5.4^{\mathrm{a}}$ & $7.9^{\mathrm{d}}$ & $43.0^{\mathrm{d}}$ \\
RFC-1 mo & $7.5^{\mathrm{e}}$ & $0.80^{\mathrm{bc}}$ & $0.07^{\mathrm{b}}$ & $4.4^{\mathrm{b}}$ & $6.0^{\mathrm{e}}$ & $26.4^{\mathrm{e}}$ \\
EPSA-1 mo & $4.2^{\mathrm{f}}$ & $0.76^{\mathrm{c}}$ & $0.07^{\mathrm{b}}$ & $4.3^{\mathrm{b}}$ & $3.2^{\mathrm{f}}$ & $13.8^{\mathrm{f}}$ \\
EPSB-1 mo & $6.0^{\mathrm{ef}}$ & $0.82^{\mathrm{abc}}$ & $0.06^{\mathrm{b}}$ & $4.4^{\mathrm{b}}$ & $4.9^{\mathrm{e}}$ & $21.3^{\mathrm{e}}$ \\
\hline
\end{tabular}

${ }^{\mathrm{a}-\mathrm{f}}$ Means within the same column with no common superscript differ $(P<0.05)$.

${ }^{1} \mathrm{RFC}=$ process cheese made from 2 -d-old reduced fat Cheddar cheese containing no exopolysaccharide (EPS). EPSA = process cheese made from 2-d-old reduced fat Cheddar cheese containing EPS produced by Lactococcus lactis ssp. cremoris JFR1; EPSB = process cheese made from 2-d-old reduced fat Cheddar cheese containing capsular EPS produced by Streptococcus thermophilus $3855 \mathrm{~S}$; RFC-blend = a 50/50 blend of young $(2 \mathrm{~d}$ old $)$ and aged $(6 \mathrm{mo}$ old $)$ reduced fat Cheddar cheese containing no EPS. Young = made from 2 $\mathrm{d}$-old base cheese, $1 \mathrm{mo}=$ made from 1-mo-old base cheese.

negative reduced fat Cheddar cheeses (Awad et al., 2005b; Hassan and Awad, 2005). Exopolysaccharides interfere with protein-protein interactions and act as a lubricant or plasticizer between proteins in Cheddar cheese, resulting in reduced firmness (Hassan and Frank, 1997; Hassan and Awad, 2005). Cheddar cheese made with EPS-producing cultures exhibited a porous structure in which the large pores were associated with visible EPS (Hassan et al., 2005). However, a compact structure with small pores was seen in Cheddar cheese made with EPS nonproducing cultures (Hassan and Awad, 2005). The modification in the protein network of the BRFCC by EPS could be one of the factors influencing hardness of reduced fat process cheese made from 2-d-old BRFCC.

The hardness of reduced fat process cheese made using 1-mo-old BRFCC was lower $(P<0.05)$ than that in cheese made using 2-d-old BRFCC (Table 4). This is due to changes in the base cheese during ripening. Such changes include proteolysis, protein hydration, water redistribution, and solubilization of colloidal calcium phosphate (Creamer and Olson, 1982; Lucey and Fox, 1993; McMahon, et al., 1999; Guinee, 2002; Lucey, et al., 2003; Awad et al., 2005a,b). The hardness of EPSA1 mo was lower $(P<0.05)$ than that in RFC-1 mo. The differences in hardness between EPSA-1 mo and RFC1 mo were greater than those between EPSA-young and RFC-young. This might be due, in part, to the larger differences in proteolysis and $\mathrm{pH}$ between the base cheeses used in making the former cheeses (Awad et al., 2005a). This finding indicates that the effect of EPS on reduced fat process cheese characteristics is limited compared with other factors such as changes that take place during first mo of base cheese ripening. Although there was no difference in hardness between 2-d-old and 1-mo-old EPSA (Awad et al., 2005b), a large difference in hardness was observed between reduced fat process cheeses made from those 2 base cheeses (EPSAyoung and EPSA-1 mo; Table 4). This clearly demonstrates that factors controlling hardness of the base cheese are not necessarily similar to those affecting reduced fat process cheese hardness.

There were no differences $(P>0.05)$ in cohesiveness among all reduced fat process cheeses made from 2-dold BRFCC (Table 4). Exopolysaccharides do not seem to affect reduced fat process cheese cohesiveness. Similar results were reported in Cheddar cheese by Awad et al. (2005b). Cohesiveness was lower $(P<0.05)$ in EPSA-1 mo than in EPSA-young. This is probably due to proteolysis in the base cheese, which disrupts the structural integrity of the protein matrix, leading to reduced cohesiveness (Irudayaraj et al., 1999).

There were no differences $(P>0.05)$ in adhesiveness between EPS-positive and EPS-negative reduced fat process cheeses (Table 4). This information is important as it shows that EPS will not affect reduced fat process cheese sliceability. The adhesiveness of reduced fat process cheeses made using 1-mo-old BRFCC was lower than that in the corresponding cheeses made from 2d-old BRFCC. During the first month of ripening, adhesiveness of BRFCC decreases (Awad et al., 2005b), which seemed to affect adhesiveness of the resulting reduced fat process cheeses.

The springiness did not differ $(P<0.05)$ among reduced fat cheeses made using 2-d-old and 1-mo-old BRFCC (Table 4). This indicates that EPS, $\mathrm{pH}$, and proteolysis in the base cheese have no effect on reduced fat process cheese springiness. Gumminess in EPSAyoung was lower $(P<0.05)$ than that in RFC-young and EPSB-young. Also, EPSB-young was less gummy than RFC-young (Table 4). The gumminess was lower in cheeses made from 1-mo-old BRFCC than in the corresponding ones made from 2-d-old BRFCC. The results in Table 4 also show that chewiness, which is the 
Table 5. Viscoelastic properties of reduced fat process cheeses ${ }^{1}$

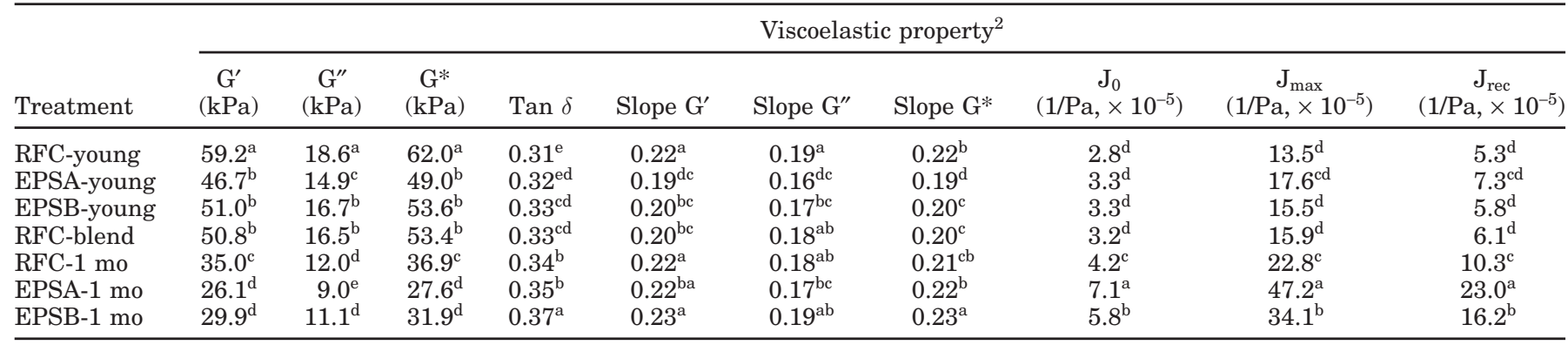

${ }^{\mathrm{a}-\mathrm{e}}$ Means within the same column with no common superscript $\operatorname{differ}(P<0.05)$.

${ }^{1} \mathrm{RFC}=$ process cheese made from 2 -d-old reduced fat Cheddar cheese containing no exopolysaccharide (EPS). EPSA $=$ process cheese made from 2-d-old reduced fat Cheddar cheese containing EPS produced by Lactococcus lactis ssp. cremoris JFR1; EPSB = process cheese made from 2-d-old reduced fat Cheddar cheese containing capsular EPS produced by Streptococcus thermophilus 3855S; RFC-blend = a 50/ 50 blend of young $(2 \mathrm{~d}$ old $)$ and aged $(6 \mathrm{mo}$ old $)$ reduced fat Cheddar cheese containing no EPS. Young $=$ made from 2 -d-old base cheese, 1 mo $=$ made from 1-mo-old base cheese.

${ }^{2}$ Elastic $\left(G^{\prime}\right)$, viscous $\left(G^{\prime \prime}\right)$, and complex $\left(G^{*}\right)$ moduli; $J_{0}=$ compliance at time zero; $J_{\max }=$ peak compliance at $150 \mathrm{~s} ; J_{\text {rec }}=$ compliance after recovery.

energy required to masticate the cheese product to a state ready for swallowing, is lower in the reduced fat process cheese made from EPSA than in that made from RFC. Chewiness and gumminess are related to cheese hardness (Table 4$)$. The chewiness was lower ( $P$ $<0.05$ ) in reduced fat process cheeses made from 1-moold BRFCC than in corresponding cheeses made from 2-d-old BRFCC (Table 4). The major differences in hardness, gumminess, and chewiness between the EPS-positive and negative reduced fat process cheeses made from 1-mo-old BRFCC may be related to a combination of several factors such as the presence of EPS, lower $\mathrm{pH}$, and more extensive proteolysis in the EPS-positive BRFCC (Awad et al., 2005a). Such factors affect the characteristics of reduced fat process cheese (Bowland and Foegeding, 2001; French et al., 2002; Glenn et al., 2003). In addition, the 3 textural parameters, hardness, gumminess, and chewiness, were lower in reduced fat process cheeses containing ropy EPS than in those containing capsular EPS. As expected, reduced fat process cheese made with the 50/50 blend of young and aged cheeses (RFC-blend) was softer and less chewy and gummy than cheeses made from 2-d-old BRFCC. Interestingly, all reduced fat process cheeses made from 1mo-old BRFCC were much softer than that made from the 50/50 blend. This finding demonstrates the impact of the changes in base cheese during first month of ripening, which might be more important than those occurring thereafter, on the characteristics of the resulting reduced fat process cheese.

\section{Viscoelastic Properties}

The EPSA-young had a smaller $(P<0.05)$ viscoelastic moduli magnitude than did RFC-young (Table 5). There were no differences $(P>0.05)$ in elasticity between EPSA-young and RFC-blend. This shows that replacing aged cheese with 2-d-old EPS-positive cheese would not affect reduced fat process cheese elasticity. The viscoelastic moduli $\left(G^{\prime}, G^{\prime \prime}\right.$, and $\left.G^{*}\right)$ of the reduced fat process cheese made using 1-mo-old BRFCC were lower $(P<$ $0.05)$ than those in the corresponding cheeses made using 2-d-old cheeses (Table 5 ). In addition, the viscoelastic moduli in EPSA-1 mo were lower $(P<0.05)$ than those in RFC-1 mo. This could be due to the presence of EPS, lower $\mathrm{pH}$, and higher proteolysis in the BRFCC used in making EPSA-1 mo (Awad et al., 2005a). Tan $\delta$ was higher $(P<0.05)$ in reduced fat process cheeses made using 1-mo-old BRFCC than in corresponding cheeses made using 2-d-old BRFCC (Table 5). This indicates a more viscous-like behavior in the former cheeses. A negative correlation could be seen between Tan $\delta$ and hardness and chewiness (Tables 4 and 5). The presence of EPS had no effect on Tan $\delta$.

Viscoelastic moduli increased with increasing frequency, which is typical for cheese (Brown et al., 2003; Hassan et al., 2005). The slopes of the viscoelastic moduli as a function of frequency were lower $(P<0.05)$ in EPSA-young than in RFC-young (Table 5), indicating less frequency dependence of the former cheese. No differences $(P>0.05)$ were found in the frequency dependence (slope of $\mathrm{G}^{\prime}, \mathrm{G}^{\prime \prime}$ ) among cheeses made from 1mo-old BRFCC. There was no difference $(P>0.05)$ in instantaneous compliance $\left(\mathrm{J}_{0}\right)$, creep strain $\left(\mathrm{J}_{\max }\right)$, and residual strain $\left(J_{\text {rec }}\right)$ among cheeses made using 2-d-old BRFCC (Table 5). This shows that the presence of EPS in the fresh base cheese does not affect reduced fat process cheese deformation. The compliances were higher in all reduced fat process cheeses made using 1mo-old BRFCC than in the corresponding cheeses made 
Table 6. Functional properties of reduced fat process cheeses ${ }^{1}$

\begin{tabular}{llcccccc}
\hline & \multicolumn{7}{c}{ Functional property $^{2}$} \\
\cline { 2 - 7 } Treatment & $\begin{array}{c}\text { Soft T } \\
\left({ }^{\circ} \mathrm{C}\right)\end{array}$ & $\begin{array}{c}\text { Melt T } \\
\left({ }^{\circ} \mathrm{C}\right)\end{array}$ & $\begin{array}{c}\text { Soft t } \\
(\mathrm{s})\end{array}$ & $\begin{array}{c}\text { Melt t } \\
(\mathrm{s})\end{array}$ & $\begin{array}{c}\text { Flow } \\
(\%)\end{array}$ & $\begin{array}{c}\text { Free oil } \\
(\%)\end{array}$ & $\begin{array}{c}\text { Free oil/ } \\
\% \text { fat }\end{array}$ \\
\hline RFC-young & $41^{\mathrm{ab}}$ & $58^{\mathrm{cd}}$ & $123^{\mathrm{a}}$ & $297^{\mathrm{a}}$ & $68^{\mathrm{bc}}$ & $0.77^{\mathrm{b}}$ & $3.63^{\mathrm{b}}$ \\
EPSA-young & $35^{\mathrm{c}}$ & $61^{\mathrm{ab}}$ & $123^{\mathrm{a}}$ & $276^{\mathrm{b}}$ & $72^{\mathrm{a}}$ & $0.63^{\mathrm{bc}}$ & $3.00^{\mathrm{cb}}$ \\
EPSB-young & $37^{\mathrm{bc}}$ & $60^{\mathrm{cb}}$ & $135^{\mathrm{a}}$ & $300^{\mathrm{a}}$ & $66^{\mathrm{c}}$ & $0.93^{\mathrm{a}}$ & $4.41^{\mathrm{a}}$ \\
RFC-blend & $44^{\mathrm{a}}$ & $63^{\mathrm{a}}$ & $127^{\mathrm{a}}$ & $282^{\mathrm{ab}}$ & $69^{\mathrm{abc}}$ & $0.75^{\mathrm{b}}$ & $3.56^{\mathrm{b}}$ \\
RFC-1 mo & $35^{\mathrm{c}}$ & $58^{\mathrm{d}}$ & $92^{\mathrm{bc}}$ & $240^{\mathrm{c}}$ & $70^{\mathrm{ab}}$ & $0.45^{\mathrm{d}}$ & $2.14^{\mathrm{d}}$ \\
EPSA-1 mo & $28^{\mathrm{d}}$ & $58^{\mathrm{d}}$ & $79^{\mathrm{c}}$ & $226^{\mathrm{c}}$ & $71^{\mathrm{ab}}$ & $0.50^{\mathrm{cd}}$ & $2.40^{\mathrm{cd}}$ \\
EPSB-1 mo & $34^{\mathrm{c}}$ & $57^{\mathrm{d}}$ & $95^{\mathrm{b}}$ & $235^{\mathrm{c}}$ & $72^{\mathrm{a}}$ & $0.52^{\text {cd }}$ & $2.45^{\mathrm{cd}}$ \\
\hline
\end{tabular}

\footnotetext{
${ }^{\mathrm{a}-\mathrm{d}}$ Means within the same column with no common superscript differ $(P<0.05)$.

${ }^{1} \mathrm{RFC}=$ process cheese made from 2 -d-old reduced fat Cheddar cheese containing no exopolysaccharide $($ EPS), EPSA = process cheese made from 2-d-old reduced fat Cheddar cheese containing EPS produced by Lactococcus lactis ssp. cremoris JFR1; EPSB = process cheese made from 2-d-old reduced fat Cheddar cheese containing capsular EPS produced by Streptococcus thermophilus 3855S; RFC-blend = a 50/50 blend of young $(2 \mathrm{~d}$ old $)$ and aged $(6 \mathrm{mo}$ old $)$ reduced fat Cheddar cheese containing no EPS. Young = made from 2 d-old base cheese, $1 \mathrm{mo}=$ made from 1-mo-old base cheese.

${ }^{2}$ Soft $\mathrm{T}=$ softening temperature; Melt $\mathrm{T}=$ melting temperature; Soft $\mathrm{t}=$ softening time; Melt $\mathrm{t}=$ melting time.
}

from 2-d-old BRFCC or the 50/50 blend. The lower elasticity and higher deformation in reduced fat process cheese made from 1-mo-old BRFCC compared with those in cheeses made from 2-d-old cheese are mostly related to more protein hydration, solubilization of colloidal calcium phosphate, and proteolysis in the base cheese used in making the former cheeses. The RFC-1 mo had lower $(P<0.05)$ creep compliances than did EPSA-1 mo and EPSB-1 mo. Among all cheeses, the highest values of instantaneous compliance $\left(\mathrm{J}_{0}\right)$, creep strain $\left(\mathrm{J}_{\max }\right)$, and residual strain $\left(\mathrm{J}_{\text {rec }}\right)$ were in EPSA$1 \mathrm{mo}$. The difference in instantaneous compliances between EPSA-1 mo and RFC-1 mo but not between EPSA-young and RFC-young could be a result of 2 factors: 1) greater differences in proteolysis and $\mathrm{pH}$ between the BRFCC used in making the former cheeses (Awad et al., 2005a), 2) ability of EPS produced during making or ripening of base cheese to affect water migration and protein hydration during first mo of ripening, or both. The viscolastic moduli were negatively correlated with $\mathrm{J}_{\max }$ in reduced fat process cheeses made from 1-mo-old but not 2-d-old BRFCC. Such negative correlation was also reported by Brown et al. (2003) and Hassan et al. (2005).

\section{Functional Properties}

Table 6 shows that the softening temperature of EPSA-young is lower $(P<0.05)$ than that in RFC-young and RFC-blend. In addition, EPSA-young melted faster and had higher \% flow than did RFC-young. This means that the EPS-positive reduced fat process cheese started to lose its elasticity at a lower temperature than did the EPS-negative cheese, which might be due to less protein matrix per unit area to soften in the former cheese. Same differences were found between BRFCC used in making the EPSA-young and RFC-young (Awad et al., 2005b). Reduced fat process cheeses (EPS-positive and negative) made from 1-mo-old BRFCC softened and melted in a shorter time than did those made using the corresponding 2-d-old cheeses. In the EPS-negative base cheese, major changes in softening properties (shorter time, lower temperature, and higher extent of flow) were seen during the first month of ripening (Awad et al., 2005b). This was due to the more hydrated and soluble protein in the 1-mo-old cheese than in the 2-d-old cheese. As protein hydration and hydrolysis increase during cheese ripening, protein-protein interactions are replaced by protein-water interactions, which increase the ability of cheese to soften and flow (McMahon et al., 1999). However, such major changes in softening were not seen in base cheese used in making the EPSA process cheese (Awad et al., 2005b). Although the softening time was much shorter in BRFCC used in making RFC-1 mo than in that used in making EPSA1 mo (Awad et al., 2005b), the opposite was seen in the reduced fat process cheeses (Table 6). This indicates that the melting properties of reduced fat process cheeses are not necessarily governed by those of the base cheese. The findings of Hassan and Awad (2005) and Awad et al. (2005a,b) showed that during the first month of ripening of reduced fat Cheddar cheese, more extensive water redistribution and protein hydration took place in the EPS-negative than in the EPS-positive cheese. In addition, the EPS-positive cheese showed more extensive proteolysis and lower $\mathrm{pH}$ than the EPSnegative one. Therefore, it can be concluded that the proteolysis level, $\mathrm{pH}$, or both in the base cheese has a 
Table 7. Sensory scores of reduced fat process cheeses ${ }^{1}$

\begin{tabular}{lcccccccccc}
\hline & \multicolumn{10}{c}{ Sensory property $^{2}$} \\
\cline { 2 - 10 } Treatment & HF & HS & FM & FC & CB & CC & CA & CS & RS & Flavor $^{3}$ \\
\hline RFC-young & $6.9^{\mathrm{a}}$ & $6.0^{\mathrm{a}}$ & $6.5^{\mathrm{a}}$ & $6.5^{\mathrm{ab}}$ & $4.1^{\mathrm{b}}$ & $4.0^{\mathrm{a}}$ & $3.9^{\mathrm{cb}}$ & $3.9^{\mathrm{d}}$ & $4.5^{\mathrm{b}}$ & $7.2^{\mathrm{a}}$ \\
EPSA-young & $5.1^{\mathrm{c}}$ & $4.9^{\mathrm{cb}}$ & $5.1^{\mathrm{cd}}$ & $6.6^{\mathrm{a}}$ & $4.9^{\mathrm{ab}}$ & $4.2^{\mathrm{a}}$ & $3.3^{\mathrm{c}}$ & $4.7^{\mathrm{cd}}$ & $4.9^{\mathrm{b}}$ & $7.3^{\mathrm{a}}$ \\
EPSB-young & $7.2^{\mathrm{a}}$ & $5.8^{\mathrm{ab}}$ & $8.0^{\mathrm{a}}$ & $5.9^{\mathrm{ab}}$ & $5.1^{\mathrm{ab}}$ & $4.4^{\mathrm{a}}$ & $4.0^{\mathrm{cb}}$ & $5.1^{\mathrm{bd}}$ & $5.0^{\mathrm{b}}$ & $7.6^{\mathrm{a}}$ \\
RFC-blend & $6.6^{\mathrm{ab}}$ & $6.2^{\mathrm{a}}$ & $6.4^{\mathrm{ab}}$ & $5.6^{\mathrm{ab}}$ & $4.3^{\mathrm{ab}}$ & $4.9^{\mathrm{a}}$ & $4.7^{\mathrm{ab}}$ & $4.6^{\mathrm{cd}}$ & $4.7^{\mathrm{b}}$ & $7.6^{\mathrm{a}}$ \\
RFC-1 mo & $5.5^{\mathrm{cb}}$ & $5.8^{\mathrm{ab}}$ & $5.3^{\mathrm{cb}}$ & $6.1^{\mathrm{ab}}$ & $5.7^{\mathrm{ab}}$ & $5.0^{\mathrm{a}}$ & $4.1^{\mathrm{cb}}$ & $5.5^{\mathrm{abc}}$ & $5.3^{\mathrm{ab}}$ & $7.1^{\mathrm{a}}$ \\
EPSA-1 mo & $4.0^{\mathrm{d}}$ & $4.2^{\mathrm{c}}$ & $4.0^{\mathrm{d}}$ & $5.6^{\mathrm{b}}$ & $6.1^{\mathrm{a}}$ & $5.9^{\mathrm{a}}$ & $5.3^{\mathrm{a}}$ & $6.4^{\mathrm{ab}}$ & $6.5^{\mathrm{a}}$ & $7.3^{\mathrm{a}}$ \\
EPSB-1 mo & $4.5^{\mathrm{cd}}$ & $4.8^{\mathrm{cb}}$ & $4.3^{\mathrm{cd}}$ & $6.0^{\mathrm{ab}}$ & $6.0^{\mathrm{a}}$ & $5.4^{\mathrm{a}}$ & $4.8^{\mathrm{ab}}$ & $6.5^{\mathrm{a}}$ & $6.5^{\mathrm{a}}$ & $7.5^{\mathrm{a}}$ \\
\hline
\end{tabular}

${ }^{\mathrm{a}-\mathrm{d}}$ Means within the same column with no common superscript differ $(P<0.05)$.

${ }^{1} \mathrm{RFC}=$ process cheese made from 2 -d-old reduced fat Cheddar cheese containing no exopolysaccharide (EPS). EPSA = process cheese made from 2-d-old reduced fat Cheddar cheese containing EPS produced by Lactococcus lactis ssp. cremoris JFR1; EPSB = process cheese made from 2-d-old reduced fat Cheddar cheese containing capsular EPS produced by Streptococcus thermophilus 3855S; RFC-blend = a 50/50 blend of young $(2 \mathrm{~d}$ old $)$ and aged $(6 \mathrm{mo}$ old $)$ reduced fat Cheddar cheese containing no EPS. Young = made from 2 d-old base cheese, $1 \mathrm{mo}=$ made from 1-mo-old base cheese.

${ }^{2} \mathrm{HF}$ = hand firmness; $\mathrm{HS}=$ hand springiness; $\mathrm{FM}=$ first bite firmness; $\mathrm{FC}=$ first bite fracturability; $\mathrm{CB}=$ chewdown degree of breakdown; $\mathrm{CC}=$ chewdown cohesiveness; $\mathrm{CA}=$ chewdown adhesiveness; $\mathrm{CS}=$ chewdown smoothness; and RS = residual smoothness of mouth coating. Scores: $1=$ low, $5=$ medium, $9=$ high .

${ }^{3} 1$ = poor, 5 = average, $9=$ excellent.

more significant effect on reduced fat process cheese meltability than protein hydration.

The EPS produced by L. lactis ssp. cremoris in the base cheese does not seem to affect the level of free oil in process cheese (Table 6 ). The free oil was much lower in reduced fat process cheeses made from 1-mo-old BRFCC than in those made from 2-d-old cheeses, indicating better emulsifying properties in the former cheeses.

\section{Sensory Assessments}

Sensory evaluation results are shown in Table 7. The EPSA-young had lower hand firmness, hand springiness, and first bite firmness scores than did RFC-young. This agrees with the instrumental analyses presented in Tables 4 and 5, which also showed that EPSA-young was less rigid than RFC-young. However, panelists found that EPSA-young was softer than RFC-blend, which is not in agreement with the instrumental measurements. The hand firmness, hand springiness, and first bite firmness were highly correlated $(P<0.05)$. Drake et al. (1999b) and Brown et al. (2003) also reported a similar observation. There were no differences in fracturability, cohesiveness, smoothness, and mouth coating among all cheeses made from 2-d-old BRFCC. Reduced fat process cheese made from 1-mo-old BRFCC received lower hand firmness and higher chewdown smoothness scores than did the corresponding cheeses made from 2-d-old BRFCC (Table 7). Texture profile analysis and viscoelastic measurements also showed that cheeses made from 1-mo-old BRFCC were less rigid than those made from 2-d-old cheese. Whereas EPSA-
1 mo had higher adhesiveness and smoothness of mouth coating than did EPSA-young, no differences in these attributes were found between the RFC- 1 mo and RFCyoung. Panelists gave lower hand firmness and springiness scores to EPSA-1 mo than to RFC-1 mo. This finding is also in agreement with the instrumental data in Tables 4 and 5. No differences were found in other sensory attributes among reduced fat process cheeses made from 1-mo-old BRFCC except the adhesiveness, which was higher in EPSA-1 mo than in RFC-1 mo. There were no differences $(P>0.05)$ in flavor between cheeses made with EMC and those made from aged cheeses, and all cheeses received flavor scores of 7.1 or higher.

\section{CONCLUSIONS}

This study provides new information on factors affecting physical properties and functionality of reduced fat process cheese particularly with regard to application of EPS-positive Cheddar cheese in making reduced fat process cheese. Reduced fat process cheese made from EPS-positive Cheddar cheese had softer texture and better flow than did the control cheese. The study also provides important information on the relationship between the physical properties of the base cheese and those of the reduced fat process cheese. The modification in the characteristics of the base cheese does not always have a significant impact on reduced fat process cheese. No relationship was found between hardness and melting properties of the base reduced fat cheese and reduced fat process cheese, which indicates that factors affecting the physical and functional properties 
of those cheeses are not necessarily the same. The effect of EPS on reduced fat process cheese characteristics is limited compared with changes that take place during the first mo of the base cheese ripening. Primary proteolysis in the base cheese seems to have more effect on reduced fat process cheese characteristics than secondary proteolysis. The study also shows that water redistribution and protein hydration during the first month of base cheese ripening seem to have less significant effect on reduced fat process cheese than other factors such as proteolysis and $\mathrm{pH}$.

\section{REFERENCES}

Acharya, M. R., and V. V. Mistry. 2005. Effect of vacuum condensed or ultrafiltered milk on pasteurized process cheese. J. Dairy Sci. 88:3037-3043.

AOAC. 2000. Official Methods of Analysis. Assoc. Off. Anal. Chem., Arlington, VA.

Awad, S., A. N. Hassan, and F. Halaweish. 2005a. Applications of exopolysaccharide-producing cultures in reduced-fat Cheddar cheese: Composition and proteolysis. J. Dairy Sci. 88:4195-4203.

Awad, S., A. N. Hassan, and K. Muthukumarappan. 2005b. Applications of exopolysaccharide- producing cultures in reduced-fat cheddar cheese: Texture and melting properties. J. Dairy Sci. 88:4204-4213.

Bourne, M. 1978. Texture profile analysis. Food Technol. 32:62-66, 72.

Bowland, E. L., and E. A. Foegeding. 2001. Small strain oscillatory shear and microstructural analyses of a model processed cheese. J. Dairy Sci. 84:2372-2380.

Brown, J. A., E. A. Foegeding, C. R. Daubert, M. A. Drake, and M. Gumpertz. 2003. Relationships among rheological and sensorial properties young cheese. J. Dairy Sci. 86:3054-3067.

Creamer, L. K., and N. F. Olson. 1982. Rheological evaluation of maturing Cheddar cheese. J. Food Sci. 62:901-907.

Drake, M. A., P. D. Gerard, V. D. Truong, and C. R. Daubert. 1999b. Relationship between instrumental and Sensory measurements of cheese texture. J. Texture Stud. 30:451-476.

Drake, M. A., P. D. Truong, and C. R. Daubert. 1999a. Rheological and sensory properties of reduced-fat processed cheeses containing lecithin. J. Food Sci. 64:744-747.

French, S. J., K. M. Lee, M. Decastro, and W. J. Harper. 2002. Effects of different protein concentrates and emulsifying salt conditions on the characteristics of a processed cheese product. Milchwissenshaft 57:79-82.

Glenn, T. A., III, C. R. Daubert, B. E. Farkas, and L. A. Stefanski. 2003. A statistical analysis of creaming variables impacting processed cheese melt quality. J. Food Qual. 26:299-321.
Guinee, T. P. 2002. Cheese Rheology. Pages 341-349 in Encyclopedia of Dairy Science. H. Roginski, J. W. Fuquay, and P. F. Fox, ed. Academic Press, London, UK.

Hassan, A. N., and S. Awad. 2005. Application of exopolysaccharideproducing culture in reduced fat Cheddar cheese. Cryo-scanning electron microscopy observations. J. Dairy Sci. 88:4214-4220.

Hassan, A. N., S. Awad, and K. Muthukumarappan. 2005. Effects of exopolysaccharide-producing cultures on the visoelastic properties of reduced-fat Cheddar cheese. J. Dairy Sci. 88:4221-4227.

Hassan, A. N., and J. Frank. 1997. Modification of microstructure and texture of rennet curd by using a capsule-forming non-ropy lactic culture. J. Dairy Res. 64:115-121.

Hassan, A. N., J. F. Frank, M. A. Farmer, K. A. Schmidt, and S. I. Shalabi. 1995. Observation of encapsulated lactic acid bacteria using confocal scanning laser microscopy. J. Dairy Sci. 78:2624-2628.

Hickey, D. K., K. N. Kilcawley, T. P. Beresford, E. M. Sheehan, and G. W. Martin. 2007. Starter strain related effects on the biochemical and sensory properties of Cheddar cheese. J. Dairy Res. 74:9-17.

Irudayaraj, J., M. Chen, and D. I. McMahon. 1999. Texture development in Cheddar cheese during ripening. Can. Agric. Eng. 41:253-258.

Kilcawley, K. N., M. G. Wilkinson, and P. F. Fox. 1998. Enzymemodified cheese. Int. Dairy J. 8:1-10.

Kilcawley, K. N., M. G. Wilkinson, and P. F. Fox. 2000. A survey of the composition and proteolytic indices of commercial enzymemodified Cheddar cheese. Int. Dairy J. 10:181-190.

Kindstedt, P. S., and J. K. Rippe. 1990. Rapid quantitative test for free oil (oiling off) in melted Mozzarella cheese. J. Dairy Sci. 73:867-873.

Klostermeyer, H., and G. Uhlman. 1998. Processed cheese manufacture. A Joha Guide. BK Giulini Chemie \& Co. OHG, Ladenburg, Germany.

Lucey, J. A., and P. F. Fox. 1993. Importance of calcium and phosphate in cheese manufacture: A review. J. Dairy Sci. 76:1714-1724.

Lucey, J. A., M. E. Johnson, and D. S. Horne. 2003. Perspectives on the basis of the rheology and texture properties of cheese. J. Dairy Sci. 86:2725-2743.

McMahon, D., R. L. Fife, and C. Oberg. 1999. Water partitioning in mozzarella cheese and its relationship to cheese meltability. J. Dairy Sci. 82:1361-1369.

Moskowitz, G. J., and S. S. Noelck. 1987. Enzyme modified cheese technology. J. Dairy Sci. 70:1761-1769.

Muthukumarappan, K., Y. C. Wang, and S. Gunasekaran. 1999. Estimating softening point of cheeses. J. Dairy Sci. 82:2280-2286.

SAS. 1999. User's Guide: Statistics, Version 8 Edition. SAS Inst., Inc., Cary, NC.

Schar, W., and J. O. Bosset. 2002. Chemical and physico-chemical changes in processed cheese and ready-made fondue during storage. A review. Lebensm. Wiss. Technol. 35:15-20.

van Vliet, T. 1988. Rheological properties of filled gels. Influence of filler matrix interaction. Colloid Polym. Sci. 266:518-524. 